УДК 504.05/06

DOI: $10.30838 / J . B P S A C E A .2312 .040719 .73 .466$

\title{
EVALUATION OF PARTICLE CONCENTRATION IN A DIESEL CAR : EXPOSURE OF DRIVER AND PASSENGERS
}

\author{
LIMAM K..$^{*} ;$ Dr. Sc. (Tech.), Ass. Prof., \\ DOUMONGUE M. ${ }^{2}$; Stud., \\ BOULBAIR A. ${ }^{3}$; Stud., \\ BENABED A. ; Postgrad. Stud. \\ .${ }^{1 *}$ Laboratory of Engineering Sciences for Environment (LaSIE), University of La Rochelle, Ave. M. Crépeau, 17042, La Rochelle \\ Cedex 01, France, tel. +33-5-46-45-86-23, e-mail : klimam01@univ-lr.fr, ORCID ID: 0000-0002-1534-4565 \\ ${ }^{2}$ Laboratory of Engineering Sciences for Environment (LaSIE), University of La Rochelle, Ave. M. Crépeau, 17042, La Rochelle \\ Cedex 01, France, tel. +33-5-46-45-72-72, e-mail : mba.ddumongue@etudiant.univ-lr.fr \\ ${ }^{3}$ Laboratory of Engineering Sciences for Environment (LaSIE), University of La Rochelle, Ave. M. Crépeau, 17042, La Rochelle \\ Cedex 01, France, tel. +33-5-46-45-72-72, e-mail : amir.boulbair1@univ-lr.fr \\ ${ }^{4}$ Laboratory of Engineering Sciences for Environment (LaSIE), University of La Rochelle, Ave. M. Crépeau, 17042, La Rochelle \\ Cedex 01, France, tel. +33-5-46-45-72-72, e-mail : ahmed.benabed@univ-lr.fr, ORCID ID: 0000-0003-4283-3636
}

Abstract. Problem statement. Our study is part of the field of Internal Environmental Quality (IEQ) of confined atmospheres. Its essence is to position the level of particle pollution in a diesel powered car. As a comparative analysis compared to the normative data, this study makes it possible to highlight the exposure of the driver and the passengers and to evaluate the health risk posed by the detected levels. Methods. In order to highlight the level of exposure to particles, drivers and users of cars, we conducted an experiment to quantify particle concentrations in a diesel vehicle in a static position following a protocol highlighting the influence of starting the engine. A metrology was implemented, mobilizing two different particle counters (GRIMM and OPC ALPHASENSE). Conclusions. The various measurements show that the levels of exposure to PM1 particles are low in both cases and in good safety conditions against the standards. The levels measured pose no risk to the health of users.

Keywords: particle pollution; environmental quality; health risk; air quality standards; diesel vehicle

\section{ОЦІНКА КОНЦЕНТРАЦІЇ ЧАСТИНОК У ДИЗЕЛЬНОМУ АВТОМОБІЛІ: ВПЛИВ НА ВОДІЯ І ПАСАЖИРІВ}

ЛІМАМ К. ${ }^{1^{*}} ; \partial$. m. н., проф., ДУМАНЖ М. ${ }^{2} ;$ cmyд., БУЛБАР А. ${ }^{3} ;$ cmyd., БЕНАБЕД А. ${ }^{4}$; асnірант

\footnotetext{
$1^{*}$ Лабораторія інженерних наук з навколишнього середовища, Університет Рошель, пр. М. Крепо, 23, 17042, Ля-Рошель CEDEX 01, Франція, tel. +33-5-46-45-86-23, e-mail : klimam01@univ-lr.fr, ORCID ID: 0000-0002-1534-4565

2 Лабораторія інженерних наук з навколишнього середовища, Університет Рошель, пр. М. Крепо, 23, 17042, Ля-Рошель CEDEX 01, Франція, phone: +33-5-46-45-72-72, e-mail : mba.ddumongue@etudiant.univ-lr.fr

${ }_{3}^{3}$ Лабораторія інженерних наук з навколишнього середовища, Університет Рошель, пр. М. Крепо, 23, 17042, Ля-Рошель CEDEX 01, Франція, phone: +33-5-46-45-72-72, e-mail : amir.boulbair1@univ-lr.fr

${ }^{4}$ Лабораторія інженерних наук з навколишнього середовища, Університет Рошель, пр. М. Крепо, 23, 17042, Ля-Рошель CEDEX 01, Франція, phone: +33-5-46-45-72-72, e-mail : ahmed.benabed@univ-lr.fr, ORCID ID: 0000-0003-4283-3636
}

Анотація. Постановка проблеми. Дослідження є частиною сфери якості замкнутого середовища. Його суть полягає в визначенні рівня частинок в повітрі дизельного автомобіля. Виконано порівняльний аналіз 3 нормативними даними. Дослідження дає змогу показати вплив на водія та пасажирів та оцінити ризик для здоров'я, пов'язаний з виявленими рівнями. Для моніторингу концентрацій забруднюючих речовин були використані два типи лічильників частинок. Ці фотометри (оптичні системи 3 лазерними променями) призначені для негайного або тривалого вимірювання рівнів часток у повітрі. Вони дозволяють миттєво i безперервно вимірювати масову концентрацію i розмір частинок пилу. Розмір вимірюваних частинок змінюється від 0,3 до 20 мкм в діаметрі. Вимірювання концентрації здійснюються одночасно на 16 каналах сканування діаметром $0,3 . .20$ мкм. Зважаючи на розмір частинок, ми зосередилися на діапазоні $0,3 \ldots 1$ мкм. Спостерігається явне збільшення рівня частинок в перші хвилини тесту. 3 самого початку роботи транспортного засобу спостерігається дегресивна тенденція. Це прискорюється початком двох фаз вентиляції, що, очевидно, викликало зниження рівня частинок. Зупинка вентиляції призводить до зростання концентрацій, що підсилюється зупинкою двигуна і більш-менш відкриттям вікон. Слід зазначити, що рівні частинок дуже 
низькі і не становлять жодного ризику для людини, 3 урахуванням граничного значення, визначеного Всесвітньою організацією охорони здоров'я. Висновок. Для того, щоб підкреслити рівень впливу частинок на водіїв та користувачів автомобілів, ми провели експеримент для кількісного визначення концентрації частинок у дизельному транспортному засобі в статичному положенні після запуску двигуна. Впроваджено метрологію, що використовує два різних лічильника частинок. Різні вимірювання показують, що рівні впливу частинок $є$ низькими і відповідають вимогам стандартів. Виміряні рівні не становлять ризику для здоров'я користувачів.

Ключові слова: забруднення частинками; якість навколишнього середовища; ризик для здоров'я; стандарти якості повітря; дизельний автомобіль

Introduction. Humans spend more than $80 \%$ of their time in confined environments. These are mainly indoor environments of buildings used for housing or offices but also means of transport such as buses or personal cars. Within these environments and given the activities they conduct, individuals are exposed to relatively high pollution thresholds [1].

The majority of cities around the world experience periods when high levels of air pollution exceed international air quality standards based on health. Some of the highest levels of air pollution can be found in expanding cities such as Delhi, in developing countries. Exposure to high concentrations is related to a wide range of acute and chronic health effects in adults and children depending on the constituents of the pollutants [2-5].

It is now accepted that particles play an important role in the health effects of air pollution. Faced with this health issue, French and European regulations are evolving, with the definition of reduction targets aimed at limiting atmospheric concentrations and limiting the potential exposure of people [6].
The majority of the scientific studies carried out on vehicle pollution concentrate on the emissions they emit, because, in spite of the tightening of the polluting emissions requirements of vehicles, the problem remains particularly relevant for the cities of the world. European Union, United States and Russia [7].

Since air renewal processes, including in vehicles, use outdoor air, we have decided, in this article, to characterize the level of particule pollution in a diesel engine with the engine running. This paper presents the results obtained and their positioning in relation to the standards in force and concludes on the exposure of the driver and the users to the measured thresholds.

Metrology and experimental protocol. As part of a static experiment, we mobilized a WOLKSWAKEN brand vehicle model GOLF with diesel engine. The manipa was conducted on the parking lot near the street of the staysail in La Rochelle in France, as illustrated in the image below, the red spot indicating the exact point of positioning of the vehicle used.

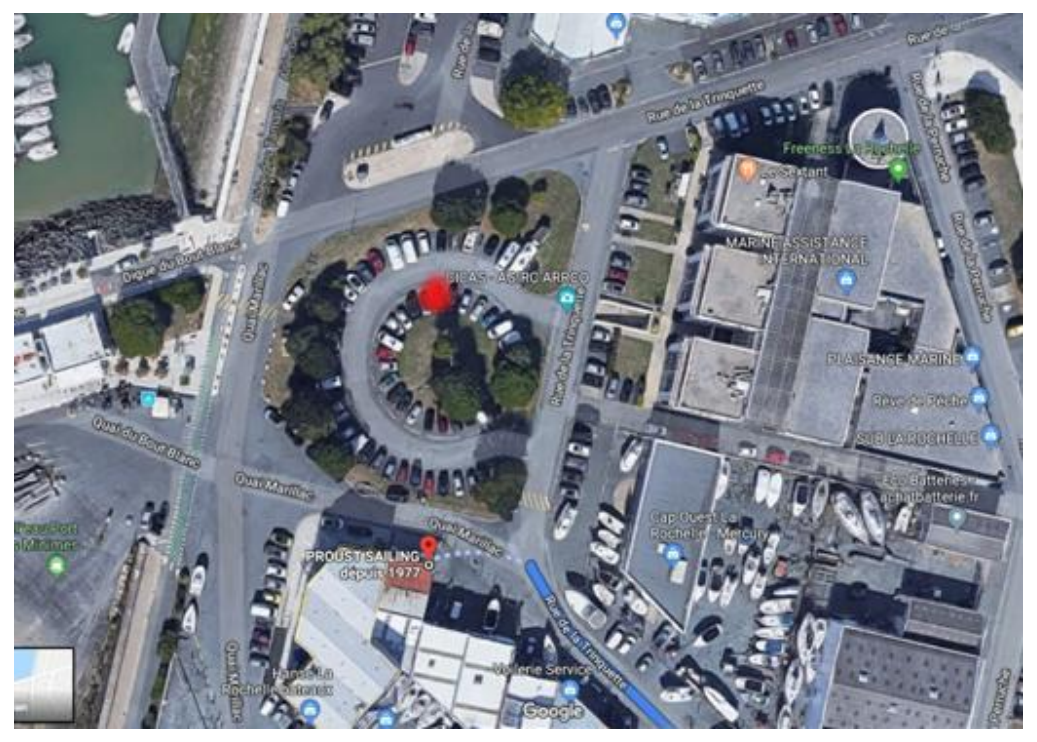

Fig. 1. Location of the experimental site 


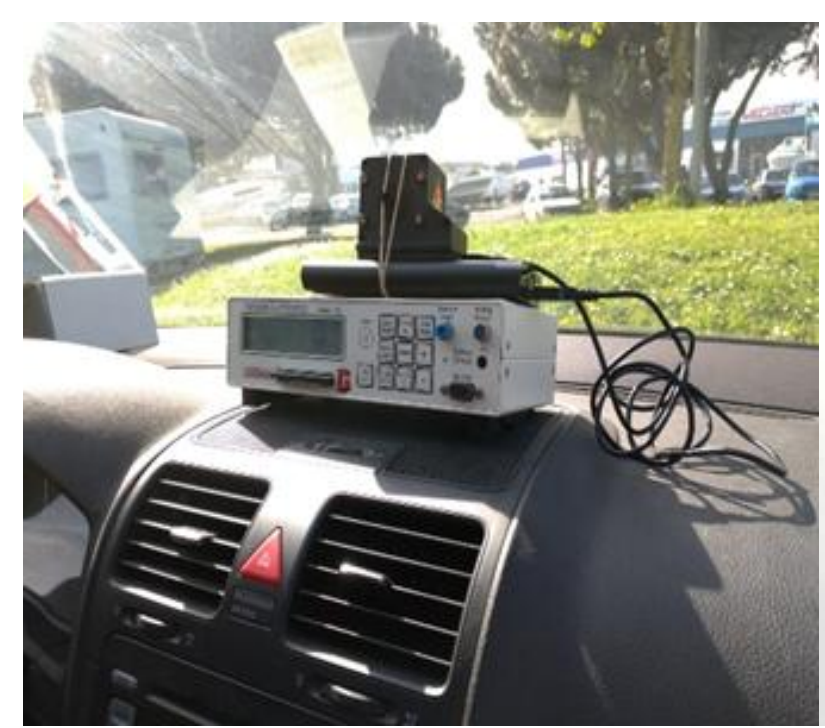

Fig. 2 : Positionning of metrology

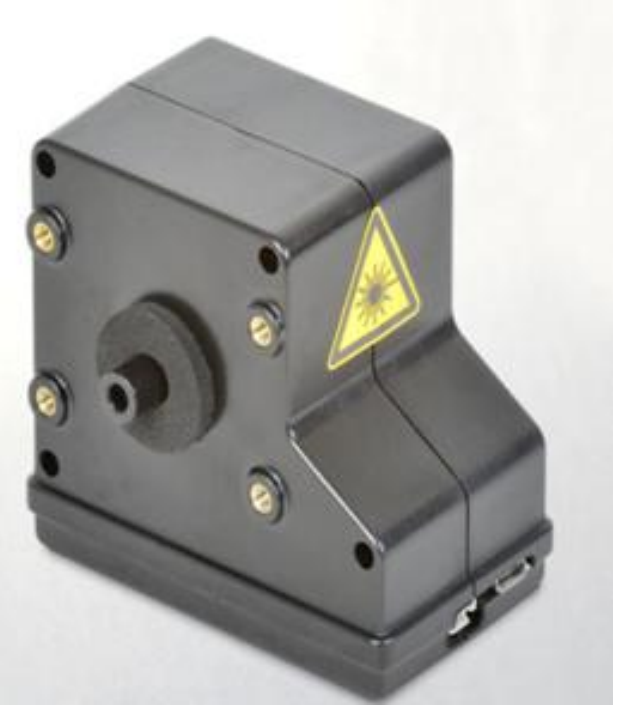

Fig. 3 : OPC ALHPASENSE N3

In order to monitor pollutant concentrations, two types of particle counters were used:

\section{GRIMM 1.108 :}

In order to monitor pollutant concentrations, two types of particle counters were used: - These photometers (optical systems with laser beams) are intended for the immediate or long-term measurement of the levels of particles in the air. They allow the instantaneous and continuous measurement of the mass concentration and the particle size of the dust. The size of the particles measured varies from 0,3 to $20 \mu \mathrm{m}$ in diameter. Concentration measurements are carried out simultaneously on 16 channels scanning $0,3 \ldots 20 \mu \mathrm{m}$ diameters. In view of the particle size present we focused on the range: $0,3 \ldots 1 \mu \mathrm{m}$. A Grimm apparatus was used and positioned on the cockpit as shown in Figure 2 below.

\section{OPC ALPHASENSE N3}

It is a particle counter that allows an assessment of the concentration of particles in the air. This device allows the instantaneous measurement of PM10, PM2.5 and PM1 particle concentrations exclusively. Our study focused on the measurement of PM1, which corresponds to fine particles, which are more harmful to health because of their ability to sink to the bottom of the lungs, even into the alveoli. The OPC is visible in Figure 2 (placed on the GRIMM). However, Figure 3 below illustrates this more clearly.

For the purpose of this experiment, we put in place a very precise and well-defined protocol, which we carried out over a five minute tent period. This protocol is detailed in the following table.

Measurement protocol

\begin{tabular}{|c|l|}
\hline Schedule & \multicolumn{1}{|c|}{ Activities } \\
\hline $11 \mathrm{~h} 08$ & Beginning of the experiment / start of counters / closed windows \\
\hline $11 \mathrm{~h} 13$ & Starting the vehicle \\
\hline $11 \mathrm{~h} 18$ & Ignition of ventilation (medium speed) / Figure 4 \\
\hline $11 \mathrm{~h} 23$ & Acceleration of ventilation (full speed) / Figure 5 \\
\hline $11 \mathrm{~h} 28$ & Cut off ventilation \\
\hline $11 \mathrm{~h} 33$ & Engine shutdown \\
\hline $11 \mathrm{~h} 38$ & Opening windows \\
\hline $11 \mathrm{~h} 43$ & Closing windows / End of the experiment \\
\hline
\end{tabular}




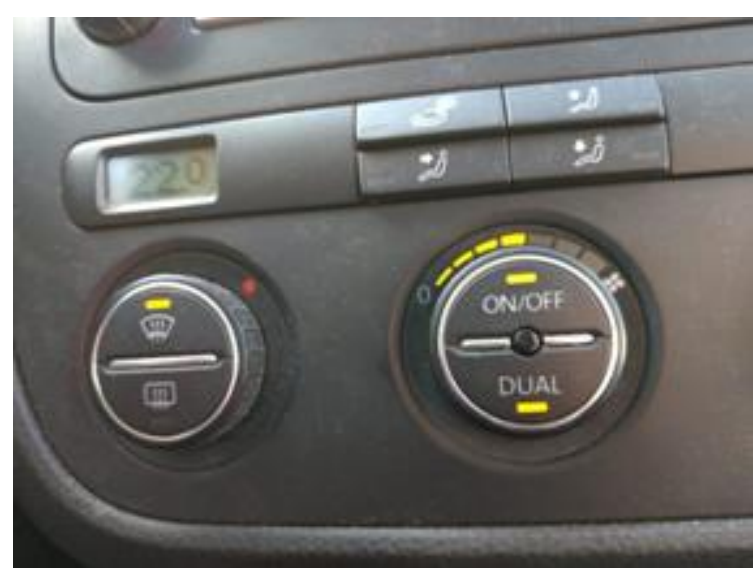

Fig. 4: Medium-cycle Ventilation

Results and discussions. After discharge of our devices we obtain the following results:

\section{GRIMM}

This graph illustrates the evolution of the level of particles measured over the period of the test. There are significant variations according to the various sequences ( 1 to 7 ) of the protocol implemented. A large particle distribution is noticeable. In any case, we measure particle levels very appreciable under the international regulations in force (the World Health Organization recommends $25 \mu / \mathrm{m}^{3}$ for a 24-hour exposure).

\section{OPC ALPHASENSE N3}

In the graph below, there is an obvious increase in the level of particles in the first

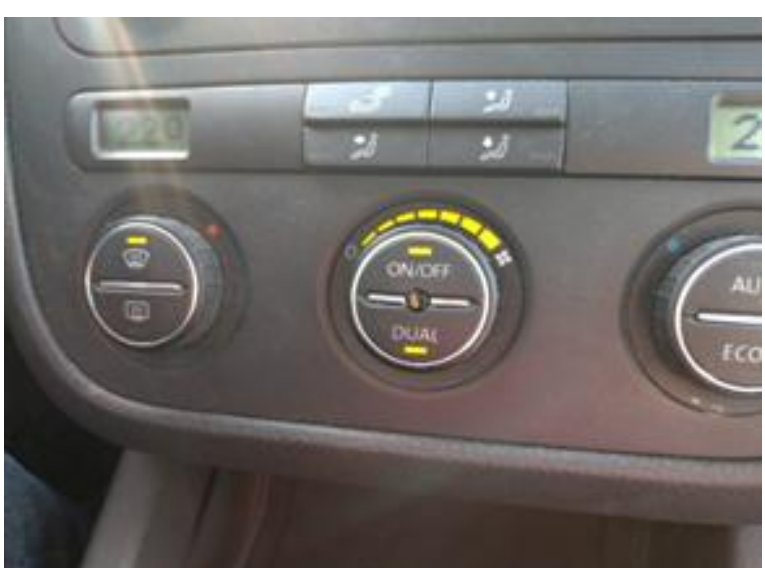

Fig. 5: Full-Flow Ventilation

minutes of the test. A degressive trend is observed from the start of the vehicle. This is accelerated by the start of the two phases of the ventilation which obviously caused the flop of the level of particles. The breakdown of the ventilation causes a rise in concentrations which is boosted by the engine shutdown and more or less by the opening of the windows. It should be noted that PM1 particle levels are very low and do not pose any risk to the individual despite their fluctuations through the phases of our measurement protocol; in view of the threshold value defined by the World Health Organization (WHO) for 24-hour exposure, ie $25 \mu / \mathrm{m}^{3}$.

\section{VARIATION IN PARTICLE CONCENTRATION}

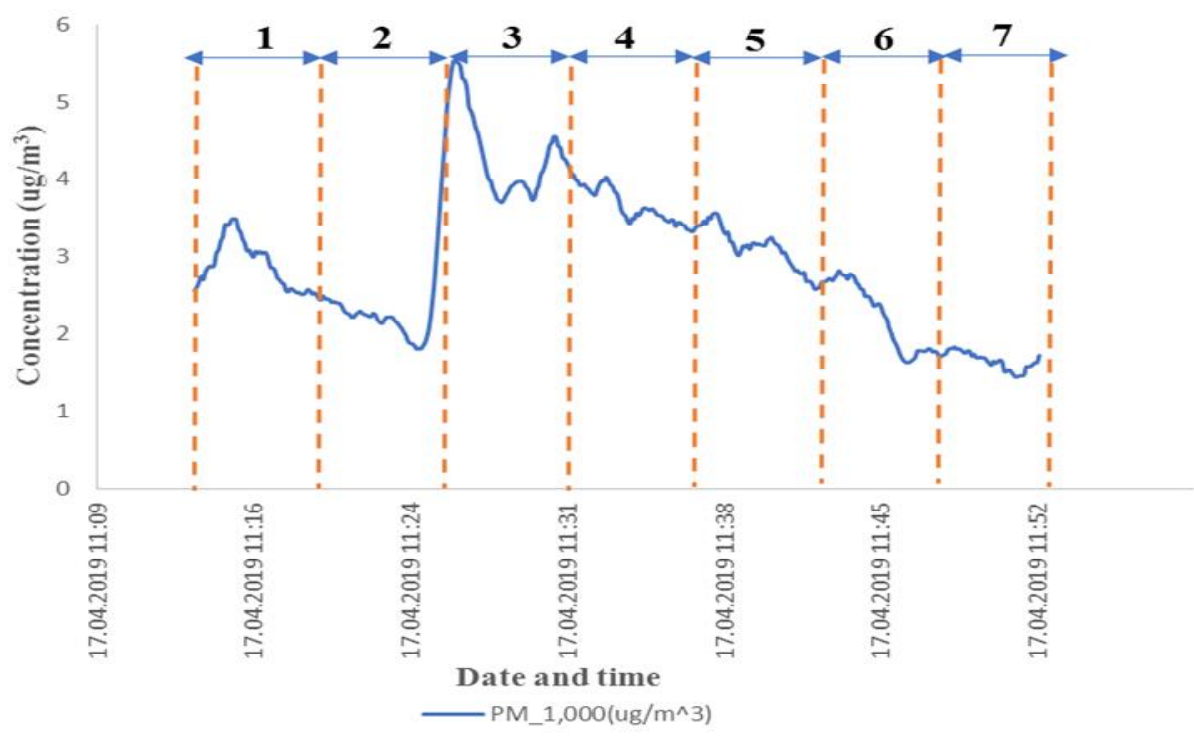

Fig. 6 : Variation in particule concentration measured by the Grimm 


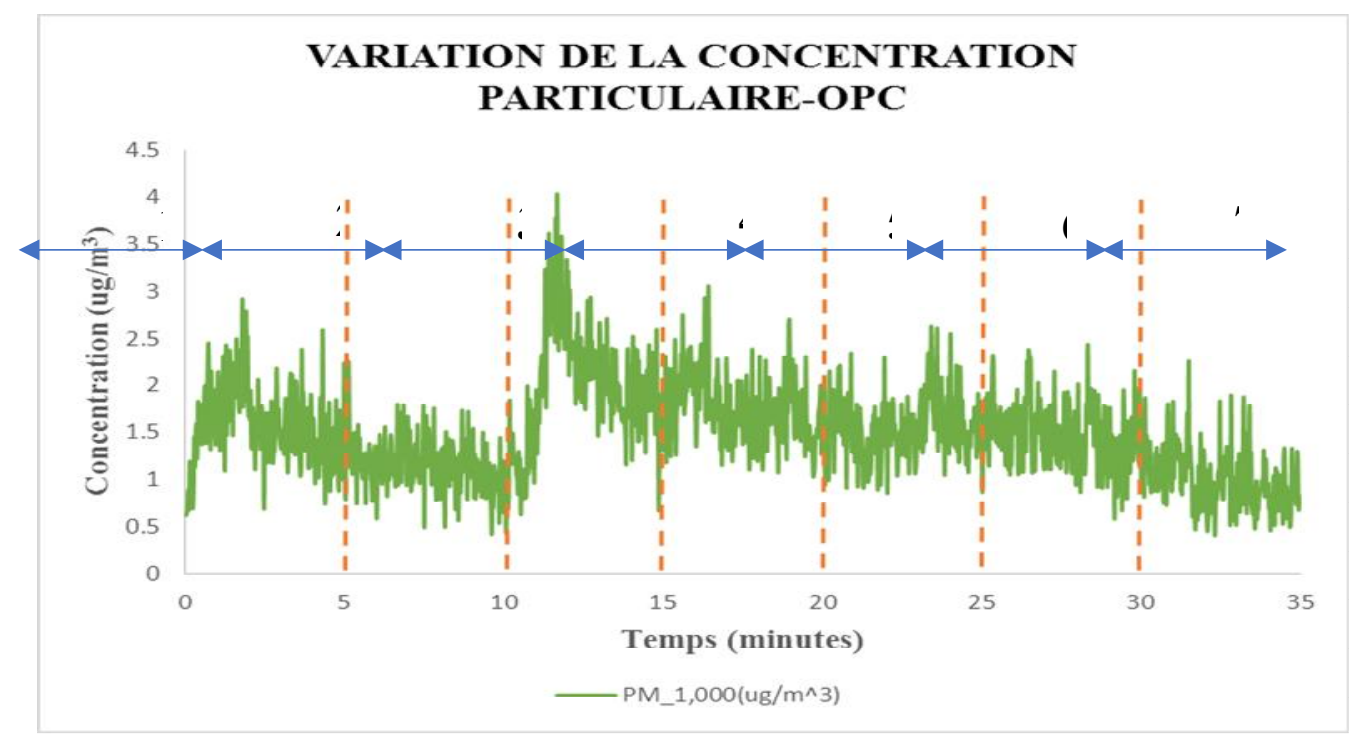

Fig. 7 : Variation in particule concentration measured by the OPC

Conclusion. In order to highlight the level of exposure to particles, drivers and users of cars, we conducted an experiment to quantify particle concentrations in a diesel vehicle in a static position following a protocol highlighting the influence of starting the engine. A metrology was implemented, mobilizing two different particle counters (GRIMM and OPC ALPHASENSE). The various measurements show that the levels of exposure to PM1 particles are low in both cases and in good safety conditions against the standards. The levels measured pose no risk to the health of users.

\section{REFERENCES}

1. Klepeis N.E., Nelson W.C., Ott W.R., Robinson J.P., Tsang A.M., Switzer P., Behar J.V., Hern S.C., Engelmann W.H. and others. The national humanactivity pattern survey nhaps: a resource for assessing exposure to environmental pollutants. Journal of Exposure Analysis and Environmental Epidemiology. No. 11(3), 2001, pp. 231-252.

2. CPCB, 2009. National Ambient Air Quality Standards, Central Pollution Control Board Notification, REGD. NO. D. L.-3300499, Ministry of Environment and Forest. Available from: Government of India http://cpcb.nic.in/National Ambient Air Quality Standards.php (accessed 17.06.2016).

3. Kumar P., Jain S., Gurjar B.R., Sharma P., Khare M., Morawska L. and Britter R. New Directions: can a "blue sky" return to Indian megacities? Atmos. Environ. 2013, no. 71, pp. 198-201.

4. Kumar P., Khare M., Harrison R.M., Bloss W.J., Lewis A.C., Coe H. and Morawska L. New directions:air pollution challenges for developing megacities like Delhi. Atmos. Environ. 2015, no. 122, pp. 657-661.

5. Kumar P., Rivas I. and Sachdeva L. Exposure of in-pram babies to airborne particles during morning drop-in and afternoon pick-up of school children. Environ. Pollut. 2017, no. 224, pp. 407-420.

6. Synthesis of knowledge on airborne particles. Airparif, 2008.

7. Franco V., Zacharopoulou T., Hammer J. et al. Evaluation of Exhaust Emissions from Three Diesel-Hybrid Cars and Simulation of AfterTreatment Systems for Ultralow Real-World NOx Emissions. Environ Sci Technol 2016, no. 50(23), pp. 13151-13159. Available from: https://doi.org/10.1021/acs.est.6b03585.

Надійшла до редакції: $\quad$ 15.06.2019 p. 